\title{
Signposts or Weathervanes? The Curious Case of Corporate Social Responsibility and Conflict Minerals
}

\author{
Ozlem Arikan $^{1} \cdot$ Juliane Reinecke $^{1} \cdot$ Crawford Spence $^{1} \cdot$ Kevin Morrell $^{1}$
}

Received: 18 November 2014/Accepted: 31 October 2015/Published online: 16 November 2015

(C) The Author(s) 2015. This article is published with open access at Springerlink.com

\begin{abstract}
Corporate social responsibility is often framed in terms of opposing constructions of the firm. These reflect, respectively, different accounts of its obligations: either to shareholders or to stakeholders (who include shareholders). Although these opposing constructions of corporate responsibility are diametrically opposed, they are also much more fluid and mobile in certain contexts, since they can act as discursive resources that are deployed and brought into play in the struggle over shaping what responsibility means. They are less the fixed, ideological "signposts" they might appear, and more like "weathervanes" that move alongside changing rhetorical currents. To show this, we analyse the Securities and Exchange Commission consultation process, and legislation, relating to the provenance of "conflict minerals". We identify two dialectically opposed camps, each seeking to influence final legislation and with end goals in keeping with the shareholder/stakeholder dichotomy. One camp lobbied for firms to scrutinize their entire supply chain, constructing the firm as a "global citizen" with very wide social responsibilities. The second camp lobbied for a lighter touch approach,
\end{abstract}

Ozlem Arikan

ozlem.arikan@wbs.ac.uk

Juliane Reinecke

juliane.reinecke@wbs.ac.uk

Crawford Spence

crawford.spence@wbs.ac.uk

Kevin Morrell

kevin.morrell@wbs.ac.uk

1 University of Warwick, Coventry, West Midlands, UK constructing the firm as a "trader", with much narrower social responsibilities. We analyse the complex interplay between these two opposed camps, our contribution being to show how both deploy competing conceptions of the corporation as discursive resources.

Keywords Auditing - Conflict minerals - Disclosure · Securities and Exchange Commission (SEC) $\cdot$ Corporate social responsibility

While long seen as a problem of state failure, the link between armed conflict and minerals sourcing has only recently gained attention as an issue of corporate social responsibility (CSR) (Reinecke and Ansari 2015). Natural deposits of precious metals such as gold ore, cassiterite (the source of tin), coltan (a key ingredient in mobile phone technology) and tungsten, fuel some of the world's most brutal conflict. The trade and supply in these minerals is helping to sustain the sale of illegal arms, and to prop up the regimes of dictators and warlords who subjugate, torture, imprison, brutalize and exploit so many. Often countries that are rich in minerals are impoverished in terms of their governance and corruption and bribery are simply the price of doing business (Agbiboa 2012; Mellahi et al. 2010). The trade in minerals that underpins contemporary technology can be seen as the continuation of a centuries old tradition of colonialism, where the natural and human resources of Africa support life in the privileged North. As Shatz (2014, p. 31) expresses it:

Africa, it's said, is the mother of modern civilisation, but it's probably more accurate to say that Congo is. Consider your mobile phone. Before it was assembled in a Chinese factory, the coltan in its capacitors may have been dug by miners in the Eastern Congo, 
where millions have died in a series of wars over 'conflict minerals 1 ,

In countries such as the Democratic Republic of the Congo (DRC), a lack of civic infrastructure and absence of governance, combined with entrenched patterns of abuse and exploitation, supports a burgeoning trade in 'conflict minerals' (Rotter et al. 2013). The DRC today is a wartorn, failed state where one child in five dies before the age of five and less than half the population has access to drinking water (Shatz 2014). Yet amidst this putrefaction, violence and poverty, corporations find cheap resources. Many of the products that the world's citizens routinely use have their roots in armed conflict in the DRC. These roots are not easy to trace since these minerals are the building blocks in highly complex manufacturing processes and are often sourced via labyrinthine supply chains. Conflict minerals criss-cross continents and companies, perhaps passing through the hands of smugglers one day only to find themselves on the conveyor belt of a high-tech manufacturing plant the next. Transport industries in the DRC are virtually unregulated and the absence of other adequately enforceable legislation on arms means that a confluence of minerals; arms and war binds together criminals; and corporations and consumers. It is not simply the geographical and financial complexities of the supply chain, but the nature of globalized manufacturing which makes locating responsibility difficult.

In this complex setting, we examine the attributions and auditing of 'conflict minerals', analysing how this issue is treated in accounting practices. More specifically, our focus is on the submissions and rulings by the Securities and Exchange Commission (SEC) and by the Supreme Court that were stimulated by the Dodd-Frank Act Section 1502. This Act essentially opened up new discursive terrain, where the ontological and ethical status of the corporation became contested. A possibility emerged: that the corporation could be construed as an ethical agent, with responsibilities analogous to human citizens. This possibility was rejected by many industry associations and corporations trading in conflict minerals, and promoted by those lobbying for greater accountability and change in this trade.

In our analysis, we map this discursive terrain and identify two dialectically opposed constructions of the corporation. On one side of the dialectic is the view of the firm as a 'trader' or nexus of contracts (Jensen and Meckling 1976); where corporations have no special social responsibilities and so stricter auditing requirements in

\footnotetext{
1 According to the 2007 survey of International Rescue Committee (IRC), estimated number of deaths due to the conflict in DRC between August 1998 and April 2007 is 5.4 million (International Rescue Committee 2007).
}

relation to supply chain transparency can be disputed purely on economical and practical grounds. On the other side of the dialectic is the view of the corporation as a moral actor or 'citizen', with responsibilities in relation to the public good (Carcello 2009; Morrell and Clark 2010; O'Brien 2009); where auditing can be used to ascribe to corporations responsibilities that extend beyond those currently enshrined in law.

This binary is familiar in terms of the rivalry between shareholder and stakeholder accounts of the firm. However, to foreshadow our findings, detailed analysis of debate on conflict minerals reveals a much more complex interplay between these two dialectically opposed constructions of corporate responsibility. In practice, either conception of the corporations - as trader or as citizen-is being mobilized by both groups with opposing goals. To analyse this, we use a distinction made famous by the former Labour M.P. Tony Benn, who talked about two kinds of politicians - those with deep, ideological roots, and those who shifted in the winds of public opinion. He memorably said of Mrs Thatcher:

The idea of a spin doctor controlling [her] was laughable. She was a signpost, not a weathervane, although she was a signpost which pointed in the wrong direction. Tony Benn

These constructions: the corporation as trader or as citizen may seem like ideological signposts, but in highly complex and contested contexts, these accounts of responsibility are more like weathervanes that shift and can be shifted by currents of rhetoric. This analysis has two principal implications. First, it shows that to understand corporate responsibility, we not only need an account of the responsible corporation, we also need empirical detail on how that account itself is mobilized as a discursive resource. This contributes to an ongoing debate in the Journal of Business Ethics in relation to whether CSR is "empty rhetoric" (Driver 2006; Kallio 2007; Sethi 2014). Second, explaining corporate responsibility in the context of conflict minerals is a rich contribution to debate on how purportedly neutral accounting practices (relating to corporate disclosure) are heavily imbued with ethical reasoning.

We begin by introducing extant literature on discourses of corporate social responsibility and accounting setting and discuss how discursive representations of the corporation impact accounting standard setting. Next, we derive opposing conceptions of the corporation as trader or as citizen. Then after posing our research question, we explain our methodology and report our empirical findings. We conclude after discussing our findings. Our analysis shows how understanding responsibility is not just simply about models of the responsible corporation, but about how these accounts are mobilized. 


\section{Discourses of Corporate Responsibility and Accounting Standard Setting}

There is now a well-established critical literature looking at how corporations present themselves discursively vis-à-vis social justice and environmental issues. In one sense, corporations resist attempts to construct themselves as anything other than economic actors. In another sense, they embrace more ethico-moral conceptions of the firm by articulating increasingly elaborate and stylized discourses around corporate social responsibility and sustainable development, often to establish their brands. Milne et al. (2006), for example, document how corporations embrace sustainability through invoking the metaphor of 'the journey', which corporations claim to have embarked upon but conveniently precludes the clear mapping of any destination that might induce significant reform in corporate behaviour. Similarly, Spence (2007) shows how companies blend economic and socio-environmental discourses in order to advance a 'win-win' ideology where the two are perceived as being mutually reinforcing. Essentially, although signifiers such as 'sustainable development' and 'corporate social responsibility' imply an opening up of accepted understandings of who the corporation is, corporate discourse is effectively employed in order to reestablish corporate hegemony of the discursive terrain (Tregidga et al. 2014). According to these views, corporate adoption of the language of sustainability and responsibility gives the impression of substantive changes to corporate activities but really only elicits second-order concessions (Levy et al. 2015; Spence 2009).

These studies usefully draw attention to the shifting and pliable character of corporate discourse on responsibility. In turn, this illustrates how CSR can become "empty rhetoric" (Driver 2006; Kallio 2007; Sethi 2014), where superficial changes merely serve to reproduce existing inequalities and entrench power relations. However, it should also be recognized that any such hegemony is established on multiple levels. Often corporate discourse on a specific issue, for instance: sustainability and conflict minerals, is heavily shaped by previous battles fought via industry bodies to shape legislative processes that furnish rules and regulations about how corporations have to account for their activities. The literature on accounting standard setting shows that the parameters around corporate disclosures are often largely set at this deeper, institutional level (Bealing 1994; Bozanic et al. 2012; Young, 2014).

Even if often presented as a technical activity, standard setting in accounting is not a value-neutral practice. Moral and political considerations are omnipresent even when looking at ostensibly technical domains such as stock options (Young 2014). This is even more evident when looking at corporate accountability in explicitly moral or ethical domains such as CSR. For example, in analysing a standard setting process in Spain which purported to expand corporate accountability into non-financial areas such as environmental impact and social responsibility, Archel et al. (2011) show how a range of different interest groups expressed multiple and conflicting viewpoints. Yet institutional outcomes reflected the interests of dominant groups such as corporations and right-wing think tanks. Archel et al. (2011) conclude that consultation processes and comment periods are subject to the mobilization of bias (Bachrach and Baratz 1970). That heretical discourses are aired, on the surface, is suggestive of dialogue and a search for compromise solutions. However, heretical discourses are inextricably caught up in a process of legitimisation: they have little impact on the institutional outcomes, but they confer legitimacy on the whole standard setting process by giving credence to standard setter claims that they have considered the viewpoints of all interested parties (Archel et al. 2011).

The SEC, the US regulator of financial markets, reflects such political activity in the construction of disclosure standards. The SEC was set up via an act of Congress in 1933 following widespread concern over corporate malfeasance and opacity in the wake of the Great Crash. Its official remit was to "prevent the exploitation of the public through misrepresentations by providing true information to investors" (Bealing, 1994, p. 556). The stated mission of the SEC today as the "Investor's Advocate" has changed little, as the following excerpt from its website confirms:

The mission of the U.S. Securities and Exchange Commission is to protect investors, maintain fair, orderly, and efficient markets, and facilitate capital formation (SEC 2014)

Yet, rather than a neutral standard setter, SEC regulation is in many ways a reflection of the interests that shape it. Bealing (1994) describes the close relationship that the SEC has with Congress, on whom it depends for its funding. Bealing (1994) argues the SEC is first and foremost concerned with legitimating itself to Congress. This leads to largely ceremonial exchanges between the two, since the SEC's ultimate objective is to sustain funding rather than deal with any substantive regulatory concerns. Similarly, Bozanic et al. (2012) draw attention to the ways in which the targets of SEC regulation (i.e. disclosing companies) can influence the regulation that they are to be subjected to. SEC regulation should not be viewed as a purely exogenous variable that companies have to conform to, but as something to be "endogenized" and built, as much as possible, in the image of the companies themselves. 
We contribute to these two strands of literature: discursive representations of the corporation and accounting standard setting. We argue that the former often pays insufficient attention to the ways in which corporate accounts are effectively pre-empted by politically charged legislative processes. It is perhaps no surprise that corporations represent themselves in the way that they do vis-àvis sustainability, and CSR given the huge time and effort that has gone into articulating a discursive position that is bolstered by institutional bodies and legislative processes. Extant research would suggest that counter-hegemonic viewpoints are only likely to be accommodated superficially and in ways that support dominant interests (Archel et al. 2011; Levy 2005; Milne et al. 2006; Spence 2007). But studies looking at the political and partisan nature of standard setting often downplay the discursive openings that even neutered legislation can potentially offer. As Levy (2005, p. 60) points out, the fact that corporations adopted the rhetoric of sustainability and conceded to reporting toxic releases enabled environmentalists to call attention to discrepancies between PR and reality and exert further pressure to reduce emissions.

\section{Conceptions of the Corporation}

Our review above indicates that previous work looking at the regulation of capital market participants has shown how the standard-setting process involves the mobilization of sectional interests and a masquerade where such interests are disguised as technical neutrality. The purpose of the present study is not to determine the success or otherwise of different strategies, but rather to understand how different actors incorporate different conceptions of the corporation into their discursive strategies.

Economists, legal commentators and management scholars have for a long-time debated competing notions of the corporation: Is the corporation a nexus of contracts, or is it a citizen? Below, we review these two prominent notions of the corporation as trader, drawing on the nexus-of-contracts theory of the corporation, and as citizen, drawing on the corporate citizenship literature. These accounts shape how the moral responsibilities, duties and obligations of a corporation and its accountability are conceptualized.

\section{Corporation as Trader}

The economic, contractarian view of the firm, generally attributed to Jensen and Meckling's (1976) Theory of the Firm, conceptualizes the firm as a nexus of contracts between different parties-primarily shareholders, directors, employees, suppliers and customers. Essentially, the firm is a "trader". Despite the constitutional, legal notion of corporate personhood, this view, which has shaped corporate law, dominated legal scholarship and perceptions about corporate responsibility, rejects that the corporation is an entity with independent existence (Jensen and Meckling 1976). Instead, the corporation, a "legal fiction", is deconstructed into a series of transactions, which presents just an alternative form of contracting to markets (Coase 1937). Consequently, the idea of a moral conscience does not square well with the notion of a fictitious entity that is nothing but an intersection of voluntary agreements.

Stressing the voluntary, market-oriented nature of contracting, this conception dismisses the notion that the corporation owes anything to the state or other stakeholders outside its contracts. Accordingly, CSR, defined as "actions that appear to further some social good, beyond the interests of the firms and that which is required by law" (McWilliams and Siegel 2001, p. 117), is thus seen outside a firm's purpose and obligation. As Margolis and Walsh (2003) note, this view holds that firms already advance social welfare in an economy, and do so best, by creating economic wealth through maximizing firm value for shareholders as residual claimants (Jensen 2002; Friedman 1970). In other words, maximizing long-term shareholder value is the one objective that best advances social welfare.

This view leads to a very narrow conception of corporate responsibilities, which, as Scherer and Palazzo (2011, p. 904) note, is based on three premises. First, as outlined in Friedman's (1970) well-rehearsed criticism of corporate social responsibility, the roles of the state and businesses should remain clearly separated so that resources are optimally allocated as different actors focus on what they do best. Addressing social problems is thus the role of the state. Second, the core responsibilities of the corporations are fiduciary responsibilities to their shareholders. Third, promoting social welfare beyond legal obligations is not a duty but a voluntary activity that is justified only if it advances long-term shareholder value (Jensen 2002). This view on corporate responsibility is reflected in studies seeking to prove the business case for CSR by demonstrating that responsible behaviour is consistent with maximizing wealth or even contributes to it (cf. Margolis and Walsh 2003).

\section{Corporation as Citizen}

An alternative conception of the corporation as "citizen" provides a different vantage point for viewing the company's role in, or responsibilities towards society or the public good (Carcello 2009; Morrell and Clark 2010; O'Brien 2009). Under the notion of "corporate citizenship", corporations have an "obligation to constituent groups in society other than stockholders" (Jones 1980, p. 59). Matten et al. (2003) argue that corporate citizenship is a descriptive term that reflects corporations' self-understanding and was 
popularized not only by academics but also by practitioners themselves, who created a discourse around being a good corporate citizen. The view stresses that the corporation is a state-created entity with legal personhood. As a person, the corporation assumes "its rightful place in society, next to other "citizens", with whom the corporation forms a community. Citizenship then focuses on rights and responsibilities of all members of the community, which are mutually interlinked and dependent upon each other" (Waddell 2000; cited in Matten et al. 2003, p. 111).

Corporate citizenship does not exclusively or even primarily mean that corporations should receive rights and duties analogous to a citizen. Instead, it means that the corporation is a public and political actor, and one that in turn plays a role in the protection and facilitation of individuals' citizen's rights (Matten and Crane 2005). This new political role of the corporation is normatively reflected in "willingness and capacity of the corporation to participate in the public process of exchanging arguments, its engagement in solving broader societal challenges, and its accountability and transparency" (Scherer and Palazzo 2007, p. 1109). As political actors, corporations can protect or underpin the rights of individual stakeholders, particularly in contexts where there is incomplete regulation (Matten and Crane 2005). The redrawing of lines separating the state and the corporation can be understood in the context of globalization. In the global economy, and where supply chains span borders, the state has often failed to act as the guarantor of social, civil and political citizenship rights. In some cases, transnational corporations have stepped into assume quasi-governmental governance duties and address social ills amid regulatory voids (Scherer and Palazzo 2011). Matten and Crane (2005) argue that the outcome is a form of "civil regulation" where transnational corporations co-create new global regimes of private governance, such as multi-stakeholder forms of CSR alongside civil society actors (Scherer and Palazzo 2007).

\section{Research Question}

In summary, the corporation as trader tends to be associated with a narrow view of corporate responsibilities while the corporation as citizen is associated with an expanded view of corporate responsibilities. Importantly, these are ideal-type representations rather than empirical descriptions of corporations. In this sense, they could be seen as signposts. In practice though, where responsibility is heavily contested and complex, they might be more fluid and mobile, serving as powerful rhetorical tools to define "rightful" corporate responsibilities. From the perspective of Laclau, the corporation constitutes a "floating signifier" (2005) the meaning of which is contested and at stake in the specific institutional struggle over the accountability of corporations vis-à-vis conflict minerals. We thus ask: how do stakeholders work with these rival conceptions of corporate responsibility, in attempts to influence legislative processes centered on responsibility and in settings that are highly complex and contested?

\section{Research Methods and Background to the Case}

The regulation of conflict minerals reporting is an appropriate context in which to explore standard-setting dynamics because there are such opposing viewpoints in relation to their auditability-and consequently the construction of the corporation. The Dodd-Frank Wall Street Reform and Consumer Protection Act was adopted by the United States in July 2010. Section 1502 of this act introduced a new reporting requirement which effectively constructed corporate responsibility for conflict minerals (Reinecke and Ansari 2015): all publicly traded companies in the US must disclose annually whether any minerals that are necessary to the functionality or production of a product of the company, originated in DRC or an adjoining country and, if so, to provide a report describing the measures taken to exercise due diligence on the source and chain of custody of those minerals, which must include an independent private sector audit of the report that is certified by the company submitting the report. Section 1502 added Section 13(p) to the Securities Exchange Act of 1934, which required the SEC to promulgate the related rules. The SEC Final Rule was adopted on August 22, 2012. Before adopting this rule, the SEC sought public comments and held a public roundtable on October 18, 2011 at which invited participants, including investors, affected issuers, human rights organizations, and other stakeholders such as auditors, discussed their views. In the consultation following the release of the draft rules in December 2010, SEC received 431 unique individual comment letters (some letters duplicated previous letters and were therefore omitted in the analysis). Table 1 shows the distribution of the comment letters coming from various stakeholders as well as conceptions used in their comment letters. As each comment letter typically uses more than one conception, the number of conceptions used are generally greater than the number of letters provided by each stakeholder. ${ }^{2}$

\footnotetext{
$\overline{2}$ Most letters used "trader" and/or "citizen" concepts. However, there were a few letters not using any of these concepts, such as letters laying out the audit types, details about mineral tracing studies, European Commission's report titled as "Tailoring trade and investment policy for these countries most in need" which is not directly related to the conflicts mineral regulation, etc. Such letters are put in the "other" category.
} 
Table 1 Stakeholder distribution of comment letters and conceptions used

\begin{tabular}{|c|c|c|c|}
\hline \multirow[t]{2}{*}{ Stakeholder type } & \multicolumn{3}{|c|}{ Conceptions used in the letters } \\
\hline & Citizen & Trader & Other \\
\hline \multicolumn{4}{|l|}{ Politician } \\
\hline 27 & 19 & 19 & 0 \\
\hline \multicolumn{4}{|c|}{ Individual investors and consumers } \\
\hline 135 & 125 & 25 & 0 \\
\hline \multicolumn{4}{|l|}{ Industry } \\
\hline 157 & 84 & 125 & 10 \\
\hline \multicolumn{4}{|c|}{ Institutional investors } \\
\hline 10 & 5 & 0 & 9 \\
\hline \multicolumn{4}{|l|}{ NGOs } \\
\hline 67 & 59 & 22 & 5 \\
\hline \multicolumn{4}{|l|}{ Governments } \\
\hline 10 & 6 & 2 & 2 \\
\hline \multicolumn{4}{|l|}{ Advisors } \\
\hline 25 & 4 & 17 & 6 \\
\hline \multicolumn{4}{|l|}{ Total } \\
\hline 431 & 302 & 210 & 32 \\
\hline
\end{tabular}

The ostensive importance of these comments letters was acknowledged by the SEC:

We have reviewed and considered all of the comments that we received relating to the rulemaking. The final rule reflects changes from the proposed rules made in response to many of these comments (SEC 2012, p. 19)

Therefore, the legislation opened up a discursive space which presented the possibility to advance a new, more morally expansive conception of the corporation.

We examined all the letters, as well as the SEC's final rule (SEC 2012) which compares the final rules to the proposed rules, and identified the issues that were discussed. We then uploaded each of the 431 unique letters into NVivo software and coded them prior to a content analysis. Two members of the research team elaborated the coding schema in early 2014 while substantive coding of the letters took place between June and August 2014. Numerous meetings took place during this time between the research team in order to review and revise the coding schema. This involved several codes being renamed, separated out into numerous new codes or, at times, amalgamated under a more general coding signifier.

The initial codes generated were essentially topic based. For example, there were codes related to 'economic consequences' of the legislation or 'what companies fell within the legislation's purview'. This first wave resulted in the identification of 42 different issue 'nodes', with references to the issue ranging from 1 at the bottom end through to
217 at the top end. See Table 2 for a sample list of the codes.

A second wave of coding was undertaken in order to ascertain political positions vis-à-vis a certain topic. A key concern here was to identify clear statements either for or against a specific proposal. For example, on the topic of 'keeping business records', 23 comments were identified. Statements in this code expressed a clear opinion either in favour (19) or against (4) issuers being forced to keep business records. As with previous research that shows the often bifurcated nature of specific-issue deliberations (Archel et al. 2011), it was generally quite straightforward to infer a clear opinion either for or against a specific proposal. Where there was ambiguity or opacity on an issue, this was classified in a third category, 'neither clearly for nor clearly against'.

In addition to coding by theme and coding by political position vis-à-vis the theme, a third and final wave of data analysis was undertaken to understand the kinds of arguments deployed by stakeholders. At this point, particular attention was paid to the diversity of different arguments advanced and the identity of the interlocutors. The more common themes articulated were identified and patterns by organization type established. Represented in the results section below are quotes that more accurately reflect the different views articulated around specific issues. The issues below were often the most frequently discussed in the comments letters. For example, the issue node giving the greatest coverage was the 'humanitarian concern' node, which was broached by 217 different contributors. However, these were often straightforward statements expressing general sympathy with the goal of resolving armed conflict in the region, serving as a prelude into more substantive issue consideration. As such, this issue node was not subject to significant additional analysis. More interesting for the purposes of analysis are those issue nodes that we perceive as reflecting the most important changes from the SEC's initial proposal or those that produced the greatest polarity or interest. It is on these issue nodes that the article focuses on primarily.

These various waves of data analysis led to the identification of two broadly grouped discursive coalitions that each coalesced around different conceptions of the corporation. In one camp, 'the corporation as trader' comprised many corporations, industry associations and other representatives such as lawyers or think-tanks and politicians who were principally from the Republican Party. The majority of their arguments was for narrowing down the liabilities of companies and centred around the economic, reputational, or legal costs and operational difficulties of implementing the conflict minerals legislation into their nexus of contracts. While publicly most industry actors felt compelled to positively acknowledge the humanitarian 
Table 2 Sample codes

\begin{tabular}{llll}
\hline Code Definition & Sample quotes & $\begin{array}{l}\text { Number } \\
\text { of letters }\end{array}$ \\
\hline
\end{tabular}

\begin{tabular}{ll}
\hline $\begin{array}{l}\text { File versus } \\
\text { Wurnish }\end{array}$ & (CMR) would require to be \\
& furnished or filed to the SEC
\end{tabular}

Given the materiality of the data in evaluating a company's risk, we urge the Commission to require all information outlined in the proposed rule to be filed in the body of the annual report rather than furnished as an exhibit" (Boston Common Asset Management

We strongly agree that CMRs should be treated as "furnished", not filed, for Exchange Act purposes. Since the purpose of CMRs (like the other Section 13(p) disclosures) is not to convey information material to investors, as such, issuers should not be responsible to investors under Exchange Act liability provisions for them (New York Bar Association Securities Regulation Committee)

$\begin{array}{ll}\text { Keeping } & \text { Whether companies should be } \\ \text { business } & \text { required to keep reviewable } \\ \text { records } & \text { business records about their } \\ & \text { supply chain to be later audited } \\ \text { about the compliance to the } \\ \text { regulation }\end{array}$

Auditor Whether independence of auditor independence of Conflict Mineral Reports would be impaired if it were also auditing the financial reports of the company

Gold

Embargo

Fighting humanitarian conflict
Whether or not should gold be treated differently because of its unique qualities

Whether or not Conflict Minerals regulation would create a defacto embargo for DRC

Acknowledging that the regulation is a necessary step in fighting the humanitarian conflict in DRC
Companies should be required to maintain business records involving DRC minerals for at least 7 years. The records must be viewable and be made available when a dispute of country of origin arises (Extractive Industries Working Group)

No requirement for reviewable business records-similarly, Section 1502 does not require the Commission to include in the new rules any requirement for an issuer to maintain reviewable business records to support its determination of the source of its conflict minerals (Cleary Gottlieb Steen Hamilton LLP)

Accounting firms other than the financial auditor (or any of numerous other qualified resources) may perform the audit that supports registrants' disclosures (CPEA Consulting)

Also if the company were required to, or chose to, make an assertion that their due diligence process as described in their Conflict Minerals Report was in conformity with the OECD Guidance, the auditor might also be subject to the independence principle described on page 31 of the OECD Guidance. That independence principle's prohibition on the auditor having provided any other service for the auditee company within a 24-month period could significantly limit the pool of auditors. (Ernst and Young)

To provide special conditions or exemptions for gold or any other mineral weakens the intent of the disclosure rules. (Calvert Asset Management)

We do not believe that the Commission's reporting standards should apply equally to all so-called conflict minerals. Gold is unique among the socalled conflict minerals (columbite-tantalite (coltan), cassiterite, and wolframite) due to the role it plays in the global financial economy and because of its chemical properties (World Gold Council)

Dodd Frank 1502 does not place a de facto embargo on minerals from the DRC. Dodd Frank 1502 is a disclosure requirement only and places no ban or penalty on the use of conflict minerals (ICAR)

This has given rise to a significant disincentive scenario to multinational and US consumers which has resulted in them avoiding purchase of metal products that contained DRC tin even if the metal producer has complied with due diligence guidelines aimed at achieving 'DRC conflict free' material as required by Dodd Frank (Malaysia Smelting Corporation)

I am pleased to hear that you have taken the step towards creating a safer world, especially a safer DRC. It is good to know that you have set the expectation that companies will either use conflict free minerals or take responsibility for not using them. Thank you for choosing to represent morality in the world (Adam Marx).

We support the underlying goal of Sec. 1502 to address the atrocities occurring in the Democratic Republic of Congo (DRC) and adjoining countries, ... we believe the proposed rule is overly burdensome and could be modified to achieve the stated goal of the Dodd-Frank Act with less burdensome measures. We believe the SEC should be mindful of President Obama's Executive Order (Executive Order 13563) "Improving Regulation and Regulatory Review," as well as the SEC's own statutory mandate to consider the effect of any new rule on "efficiency, competition, and capital formation (Advanced Medical Technology Association) 
Table 2 continued

\begin{tabular}{|c|c|c|c|}
\hline Code & Definition & Sample quotes & $\begin{array}{l}\text { Number } \\
\text { of letters }\end{array}$ \\
\hline Phase-in period & $\begin{array}{l}\text { Whether companies could be } \\
\text { granted a period before the } \\
\text { regulation became fully effective } \\
\text { to get prepared for it }\end{array}$ & $\begin{array}{l}\text { Global Witness is calling for the SEC to publish strong rules that do not } \\
\text { contain a delay or phase-in period and that incorporate internationally } \\
\text { agreed due diligence standards as published in } 2010 \text { by the Organisation } \\
\text { for Economic Cooperation and Development (OECD). Publication of the } \\
\text { rules to accompany Section } 1502 \text { has been delayed since last April. This } \\
\text { long wait has caused uncertainty within industry. Although some } \\
\text { companies have begun taking steps ahead of the rules' publication, others } \\
\text { have stated that without final rules, they are unsure of the law's } \\
\text { requirements. Further delays risk undermining progress on industrywide } \\
\text { supply chain due diligence initiatives (Global Witness) } \\
\text { As discussed in our March 2, } 2011 \text { comments, IPC strongly supports a } \\
\text { phased implementation of the conflict minerals regulation to better align } \\
\text { regulatory requirements with developing traceability and transparency } \\
\text { systems (IPC-Association Connecting Electronics Industries }\end{array}$ & 132 \\
\hline $\begin{array}{l}\text { First } \\
\text { amendment }\end{array}$ & $\begin{array}{l}\text { Whether requiring companies to } \\
\text { disclose that they are not DRC } \\
\text { Conflict free is against the First } \\
\text { Amendment Right }\end{array}$ & $\begin{array}{l}\text { Constitutional lawyers may point out that the Proposed Rules could have } \\
\text { First Amendment issues in that they force companies to make public } \\
\text { statements as to whether their products are or are not from the DRC region. } \\
\text { Such statements are inherently political because they convey certain } \\
\text { judgments against sovereign governments in the DRC region. These } \\
\text { statements are meant to carry certain negative connotations against } \\
\text { specific sovereign nation states. Such a requirement is unprecedented } \\
\text { (Taiwan Semiconductor Manufacturing Company, Ltd.) }\end{array}$ & 3 \\
\hline
\end{tabular}

purpose of the legislation, they focused on the contractual challenges. A spokesperson for General Electrics stated at the SEC Roundtable (SEC 2011, p. 12):

a company like General Electric has many, many thousands of suppliers that provide items containing conflict minerals. And many of these suppliers are suppliers of complex equipment themselves, who have, again, thousands of suppliers in their supply chains.

The question was thus treated as one of how conflict-free mineral sourcing could be contractually passed down on suppliers. Here, General Electric thus continued to argue that such contractual agreements would be impossible to implement:

when we issue a contract, the contract can't say that everything in a complicated piece of equipment has to be from a verified smelter, because there's no way for a supplier to comply with that. (ibid., p. 29)

Even if companies that were in principle willing to make due diligence efforts argued for the necessity of a generous phase-in period to impose new contract terms and flow down requirements because "it takes time, even to be able to contractually obligate our direct suppliers" (ibid.) to trace minerals.

The other camp, 'the corporation as citizen', comprised a more heterogeneous group including NGOs, investors, individuals and politicians in favour of stricter regulation.
Seeking to advance a strict interpretation of the legislation, these stakeholders claimed that corporations had a responsibility to stop or at least not to be involved in a humanitarian conflict. In his opening statement at the SEC Roundtable (SEC 2011, p. 38), Senator Durbin, a sponsor of the legislation, summarized the main argument of the "citizen" coalition,

This is a question of corporate responsibility. I won't delve into this whole debate about whether a corporation is a person, a citizen, a voter or anything like that, but I do believe having spoken to the leaders of some of the most outstanding corporations in our country that they want to do the right thing. I think you can show them that path, a reasonable path that will not only give them a clear conscience in the way they conduct business, but have a measurable, positive impact on this part of the world.

Some groups were difficult to position as they floated around either side of the antagonistic frontier. Beyond this, it became apparent that groups belonging to one of the two broad discursive coalitions also might advance a conception of the corporation that was more consistent with the discursive strategies of the opposing discursive coalition. It is these 'counter-intuitive' articulations that are revelatory of actors' different discursive strategies and we pay specific attention to them below along with depicting actor's more orthodox discursive responses to specific issues pertaining to the legislation. 
Of the 431 unique letters we analysed, 157 mainly belonged to the "corporations as traders" camp, consisting of corporations and their representatives, 212 mainly belonged to the "corporations as citizens" camp, consisting of NGOs, individual investors and consumers, and institutional investors. 62 of those letters belonged to the third category who could be in either camp depending on their political background, the country they were representing, or the subject matter being discussed; advisors, politicians and government representatives belonged to this group. See Table 1 above for the numerical distribution of commentators. In the following section, we illustrate the discursive strategies of each opposing camp, showing how they each advance different conceptions of the corporation, in often contradictory and counter-intuitive ways, in an attempt to influence the legislative process.

\section{Findings}

\section{Citizens Talking Like Traders}

The debate about the legal status of disclosure requirements revealed how a coalition of NGOs and ethical investors - who would be associated with a 'corporation as citizen' construction of responsibility_also mobilized the 'corporation as trader' construction when convenient to justify expanded responsibilities. The SEC's proposal stated that conflict minerals reports would have to be furnished, rather than filed. The distinction is important because if a disclosure is filed rather than furnished, the corporation who made that disclosure is liable for any misleading statements. Misleading statements in disclosure always bring some legal sanction, but the Securities and Exchange Act involves additional liabilities to investors who traded depending on the misleading statement filed with the SEC. Several commentators argued that conflict minerals posed reputation and supply chain risk, and therefore disclosures about conflict minerals were no different than other financial disclosures that were being filed. For example, in its letter February 1 2012, Boston Common Asset Management, an institutional investor, says

Given the materiality of the data in evaluating a company's risk, we urge the Commission to require all information outlined in the proposed rule to be filed in the body of the annual report rather than furnished as an exhibit. This will allow investors greater assurance that conflict minerals disclosure is as comprehensive, transparent and accurate as possible.

Similarly, Enough, an NGO writes on March 2 2011:

Enough recommends, however, that the Commission require issuers to file their Conflict Minerals Report, including the audit report, with the Commission, rather than simply furnish a copy. This distinction between "filing" the report, and simply furnishing such a report, is significant because it promotes greater transparency, makes Section $1502^{3}$ more effective, and is consistent with the statute's intent and legislative history.

Beyond the file versus furnish debate, the proposal required issuers to maintain reviewable business records supporting its conclusion that its conflict minerals did not originate in the covered countries based on its reasonable country of origin. Several "citizens" agreed with the proposal and gave examples of business record maintenance requirements of traders such as brokers and dealers, suggesting that records about conflict minerals were not different than other records of traders. In its comment letter dated February 28, 2011, Global Witness, an NGO, says:

If companies are going to be held accountable for their conflict minerals disclosures, they should be required to retain these records for a sufficient period of time to allow for review by the Commission or other regulatory authorities. For example, the Commission generally requires registered broker-dealers and investment advisers to retain most business related records for a period of three to 6 years.... The general five-year statute of limitations applicable to material misstatements also provides a useful benchmark

Interestingly, Global Witness here uses a more traderesque argument of "supply chain complexity", arguing that maintaining business records for at least 5 years is necessary:

Discovery of conflict mineral abuses, just like the discovery of information suggesting false or misleading statements by issuers, often occurs more than one year after the conduct takes place or the statement is made. Indeed, some industry sources have informed us that it can take many months for a batch of minerals to make their way through the whole supply chain.

Similarly, CPEA Consulting, an advisory firm, says on its letter dated October 31 2011:

It is standard practice for there to be a requirement for documents and records that form the basis for compliance with other regulations to be maintained and available for a prescribed period of time.

\footnotetext{
${ }^{3}$ Section 1502 refers to the section of The Dodd-Frank Wall Street Reform and Consumer Protection Act which mandates the conflicts minerals regulation.
} 
The SEC changed the proposal and did not put the requirement of maintaining business records in its final rule, in spite of recognizing that most commentators thought otherwise (SEC 2012 p.160).

Some traders expressed concern that the legislation would lead to a de facto economic embargo on all minerals mined in the DRC (see below). Only a few NGOs acknowledged the embargo as a potential problem (e.g. Global Engagement Pact and Southern African Resource Watch). Other NGOs, such as Enough (March 2 2011), argued against the likelihood of such an embargo in a way that reified existing corporate priorities:

On the contrary, Congo's mineral reserves are too great for world markets to ignore. For example, Congo's supply of tantalum accounts for at least $25 \%$ of the world's global supply.

This evocation of global financial interests via the construct of 'world markets', something that Enough elsewhere in its discourse appeared to be fundamentally critical of, illustrates how NGOs evoked 'corporation as trader' rhetoric, in an attempt to debunk what they saw as scaremongering on the embargo issue.

\section{Traders Talking Like Traders}

The OECD guidelines (OECD 2013) ${ }^{4}$ are the only nationally or internationally recognized due diligence standards on the conflict minerals issue. These guidelines prohibit a Conflict Minerals Report auditor from having provided any other service for the company within a 24-month period. In response to this, audit firms and companies argued that such a prohibition would dramatically decrease the pool of auditors. Audit firms also claimed that they did not see any reason that auditing a company's financial statements would jeopardize auditor independence when it comes to auditing the conflict minerals report but did not give any reason to back up such claims. For example Deloitte (March 2 2011) wrote:

we do not believe that an external financial statement auditor's independence will be impaired if the auditor were also to perform the IPSA (Independent Private Sector Audit) of the issuer's Conflict Minerals Report.

In its final ruling, the SEC clarified the independence standards and allowed a company's auditor of the financial reports to also audit the conflict minerals, in contrast to the OECD guidelines (OECD 2013) and justified this with the following remarks:

\footnotetext{
4 The guidelines were published originally in 2011 and were updated in 2013 to include the gold supplement, which was published in 2012.
}

Conflict Minerals Statutory Provision only requires an audit and no other functions that may imperil independence, such as "management functions" described in Rule 2- 01(c)(4)(vi) of Regulation S-X. Therefore, we do not believe that it would be inconsistent with the independence requirements in Rule 2-01 of Regulation S-X if the independent public accountant also performs the independent private sector audit of the Conflict Minerals Report. (SEC 2012, p. 216)

It is very curious that Regulation S-X (United States Code 2012), legislation that came into force following perceived excess in the provision of non-audit services, is invoked here in order to justify the provision of non-audit services. Both Regulation S-X and the OECD guidelines (OECD 2013) are clear about the potential compromise of independence that the provision of such services can bring about.

Advocating a narrow conception of responsibility, some industry participants asserted that gold should be treated differently than the other three conflict minerals because of its unique qualities, bringing in cost considerations. For example, Tiffany\&Co (February 22, 2011) said:

Including gold in the definition of "conflicts materials" is impractical and could lead to unintended burdens because (a) the Democratic Republic of the Congo (the "DRC") accounts for only a miniscule amount of the global gold supply $(0.3 \%$ of the newlymined gold on the market in 2009) and (b) refined gold bullion generally consists of gold from multiple sources that is smelted together, making it impossible to trace such gold back to any particular source unless the smelter employs single source batch input.

Similarly, Barrick Gold Corporation (February 28, 2011) said:

With respect to the content of the audit report, we are concerned that it has the potential to expose sensitive information about, among other things, transportation routes and storage facilities, which raises serious security concerns and could put staff of the mining company, smelters and refineries and others at risk. The risk is particularly acute in the case of gold, given the high value of this commodity.

The SEC kept it proposal as is and did not offer an exception to gold in the final rule.

Traders, at least on the surface, applauded the efforts to cease the humanitarian conflict in the DRC, but then very quickly veered onto the costs of ceasing such conflict. For example, in its letter dated March 2 2011, American Apparel and Footwear Association wrote 
While we support efforts to prevent Conflict Minerals to enter into global supply chains, including the supply chains of our member companies, we are concerned that application of this regulation may have unintended adverse consequences for apparel and footwear companies.

In a few cases, traders did not even acknowledge the regulation's benefits for reducing the humanitarian conflict and focused purely on the adverse economic consequences of the regulation (see letters of Washington Legal Foundation, an establishment which describes itself as a nonprofit organization promoting limited government, March 30 2011, Taiwan Semi-Conductor Company Limited, January 27 2011, and Tiffany\&Co, February 22 2011).

\section{Traders Talking Like Citizens}

Interestingly, in addition to using "trader" argument in an attempt to have gold exempted, traders also used a "citizen" argument for the same purpose. World Gold Council (the trade association for the gold industry), in its letter dated February 28, 2011, highlighted the humanitarian uses of gold:

We are concerned, however, that certain aspects of the Proposed Rules will actually work to the detriment of the statute's humanitarian goals. For example, gold is crucially important to certain pharmaceuticals and lifesaving medical treatments. Any regulation that increases the costs of these pharmaceuticals or treatments or that discourages companies from conducting medical research involving the use of gold should be avoided.

In launching a challenge to the moral legitimacy of the legislation itself, many opponents mobilized a discourse around corporations as concerned "citizens", stating that they worried about the unintended consequences of the legislation for artisanal miners. In that view, the legislation would lead to a de facto embargo being implemented in the DRC to the harm of poor communities. For example, Viasystems Group, Inc. (August 9, 2012) argued that the conflict minerals rule

may result in a de facto embargo on minerals mined in the Congo, leaving many legitimate miners without means to provide for their families.

Chuck Blakeman, an entrepreneur trading in Congolese minerals, blamed NGOs for the de facto embargo and copied a portion of his correspondence with Enough, an NGO which had been very active in campaigning on conflict minerals, to his letter the SEC.
You [Enough] and your organization continue to deny the fact that there is a de facto embargo, but we cannot find a buyer... of artisanal coltan... Only a few of the lowest of the low [buyers] are hanging out in Goma [Congolese mining town] buying coltan at as little as $30 \%$ of what it sold for before you told everyone Congolese minerals were evil.

The embargo argument was mostly used for a phase-in period, which was essentially a delay for the full enactment of the regulation. For example, Chuck Blakeman, once again argued (November 18, 2011):

Time is of the essence. Starvation does not wait for the slow machinations of bureaucracy. Please act quickly to provide a grace period.

Traders also asserted that the proposed legislation would violate the First Amendment: the citizen's right to free speech. The main grounds for this were that the rules would compel speech that is not of a commercial nature and would require some issuers, such as those unable to determine the status of their conflict minerals, to provide false, stigmatizing information (SEC 2012). For example, Tiffany\&Co (February 22 2011) said:

Perhaps the most fundamental concern is that the proposed regulations would compel speech in a manner that violates the First Amendment. Specifically, the proposed regulations would require companies which use gold and certain other minerals to state publicly that their products support human rights violations, even when there is no reason to believe that is true.

On April 14 2014, The United States Court of Appeals decided in National Association of Manufacturers et al. vs. $S E C$ that requiring companies to declare whether their products are "DRC conflict free", unconstitutionally compelled commercial speech, thus violating the First Amendment. The Court ruled:

At all events, it is far from clear that the description at issue-whether a product is "conflict free"-is factual and non-ideological. Products and minerals do not fight conflicts. The label "conflict free" is a metaphor that conveys moral responsibility for the Congo war. It requires an issuer to tell consumers that its products are ethically tainted, even if they only indirectly finance armed groups. An issuer, including an issuer who condemns the atrocities of the Congo war in the strongest terms, may disagree with that assessment of its moral responsibility. And it may convey that "message" through "silence." 
This ruling supports the interests of the "corporation as trader' coalition, but it is predicated on an anthropomorphization of the corporation. Moreover, the corporation is afforded rights we understand in terms of personhood. Both of these are logically closer to the 'corporation as citizen' construction of CSR.

On April 29 2014, SEC commented on the effect of the court ruling, pointing out that most aspects of the conflict minerals rule were not affected by First Amendment objections. Thus, companies were expected to file any reports required under Rule 13p-1 on or before the due date of May 2014. However,

No company is required to describe its products as "DRC conflict free," having "not been found to be 'DRC conflict free,", or "DRC conflict undeterminable." If a company voluntarily elects to describe any of its products as "DRC conflict free" in its Conflict Minerals Report, it would be permitted to do so provided it had obtained an independent private sector audit (IPSA) as required by the rule."

On the other hand on April 282014 two SEC commissioners, Daniel M. Gallagher and Michael S. Piwowar individually published a "Joint Statement on the Conflict Minerals Decision":

We believe that the entirety of the rule should be stayed, and no further regulatory obligations should be imposed, pending the outcome of this litigation...A full stay is essential because the district court could (and, in our view, should) determine that the entire rule is invalid.

This suggested that there was a split within the SEC on the matter. The Court did not determine the entire rule to be invalid, and companies submitted their first Conflict Minerals Report to the SEC as planned. At the time of writing, aspects of the legislation were still being contested.

\section{Citizens Talking Like Citizens}

Seeking to advance a strict interpretation of the legislation, several stakeholders claimed that corporations had a responsibility to stop or at least not to be involved in a humanitarian conflict. As the faith group A Thousand Sister's Outcry for Congo (December 15 2010) argued: "major U.S. industries simply cannot be allowed to continue profiting from the blood and suffering of the Congolese people". Similarly, senior school students from Idaho wrote (May 31 2012):

We are writing to you because legislation has been passed, Section 1502 in the Dodd-Frank Act, that would make it much more difficult for these rebel groups to make money by selling conflict minerals. Without these profits rebel groups will have a much harder time continuing their violent activities. However, we are frustrated that these rules are being held up and watered down in the Security and Exchange Commission. Some people are even calling for the Section 1502 to be repealed because it causes extra expense to American companies. The electronics companies in question are some of the most profitable and innovative in our nation. We are confident that they can afford to support human rights and figure out how to make this process work, even in the very complex situation presented in the DRC.

Citizenship responsibilities obliged companies to take actions to resolve this conflict even if such a responsibility "may be lost in pursuit of profit" (Presbyterian Church, February 15 2012). Advocating stakeholders included individuals who were concerned about the conflict, investors, NGOs, politicians, as well as companies who had already taken steps to make their supply chains more responsible. For instance, under the fitting header of the "Electronic Industry Citizenship Coalition" (EICC), a group of electronics companies supported the development a conflict-free smelter programme in response to civil society pressures.

Many citizens argued against a gold exemption as gold was one of the primary drivers of the conflict in DRC. For example, an investor group wrote (February 1 2012):

Reporting standards should be consistent with the statutory language of Section 1502 and should therefore apply disclosure rules equally to all stipulated conflict minerals-namely tin, tantalum, tungsten and gold. For example, gold has been a key contributor to conflict financing in the DRC.

Most NGOs also argued against a phase-in period. For example, International Corporate Accountability Roundtable (ICAR), a coalition of human rights groups including Amnesty International, EarthRights International, Global Witness, Human Rights First, and Human Rights Watch. ICAR, along with their partner Enough, said the following in its letter dated August 24 2011:

The sad reality is that the majority of businesses will not live up to their responsibilities until legally compelled to do so. A delay in the implementation of the law means further scope for armed groups in Congo that kill and rape to finance themselves via the minerals trade.

The final rule modified the proposal and provided a transition period for all companies for 2 years and for smaller companies for 4 years. 


\section{Discussion}

The differing viewpoints identified from the comments letters can be viewed as struggles over a different conception of what, or perhaps who, the corporation is. On one side of the antagonistic frontier is a coalition of mining companies, manufacturing organizations and professional service firms who are predictably either against the legislation per se, or in favour of a very light-touch interpretation of it. This group coalesce around a 'corporation as trader' construction of CSR. This denotes a very narrow economic interpretation as even investor-centric concerns relating to risk management are often excluded. Indeed, there is a fundamental contradiction here in that the nexus of contracts view generally posits shareholder primacy, but the evidence presented locates investors on the opposing side of the antagonistic frontier from corporations. Ethico-moral concerns are not written out of this coalition. Indeed, the notion that companies do not have responsibilities for armed conflict in the Congo-which is broadly what underpins the discourse of this coalition-is itself an ethico-moral stance.

On the other side of the antagonistic frontier is a coalition of investors, NGOs, interested individuals and various politicians and civil servants who were broadly in favour of the legislation per se and often keen to advance a wider and farther reaching interpretation of it. We refer to this group here as coalescing around a "corporation as citizen' construction of CSR. Implicit within this conception is both a far-reaching understanding of economic consequences (encompassing risk management concerns of investors); and of ethico-moral considerations-in that it sees the resolution of conflict in the DRC as something corporations are in some way responsible for.
Often those on the 'corporation as citizen' side of the frontier would evoke 'corporation as trader' arguments to appeal to the sensibilities of legislators. Equally, those on the 'corporation as trader' side of the frontier would evoke humanitarian concerns or 'corporation as citizen' arguments in order to argue against the proposed legislation. Understanding CSR in this setting is therefore not a simple case of different signposts pointing either to "corporation as citizen' or 'corporation as trader'. Rather, both conceptions are articulated and advanced by each coalition. The meaning of the corporation itself is brought into question by the legislation, but different groups seeking to advance a particular vision of who the corporation is, will mobilize the vision of their opponents in order to win specific battles. Rather than signposts or clear ideological coordinates-these constructions shift and take on new senses depending on whichever argument seems to advance a cause best.

To highlight this more specifically, a complex, seemingly counter-intuitive discourse emerges from each coalition. As seen in Fig. 1, expanded conceptions of the corporation are advanced by those who seek to ultimately circumscribe corporate accountability, whereas conversely, circumscribed conceptions of the corporation are advanced by those who seek to ultimately expand corporate accountability.

Future research might usefully explore the relative success of mobilizing counter-intuitive discourses, or of adopting the language of one's opponents. The present study has been less concerned with the efficacy of different strategies than with understanding the conceptual composition of different discursive strategies. With the passage of time, it will be easier to determine the efficacy or otherwise
Fig. 1 Conceptions of the corporation as discursive strategy

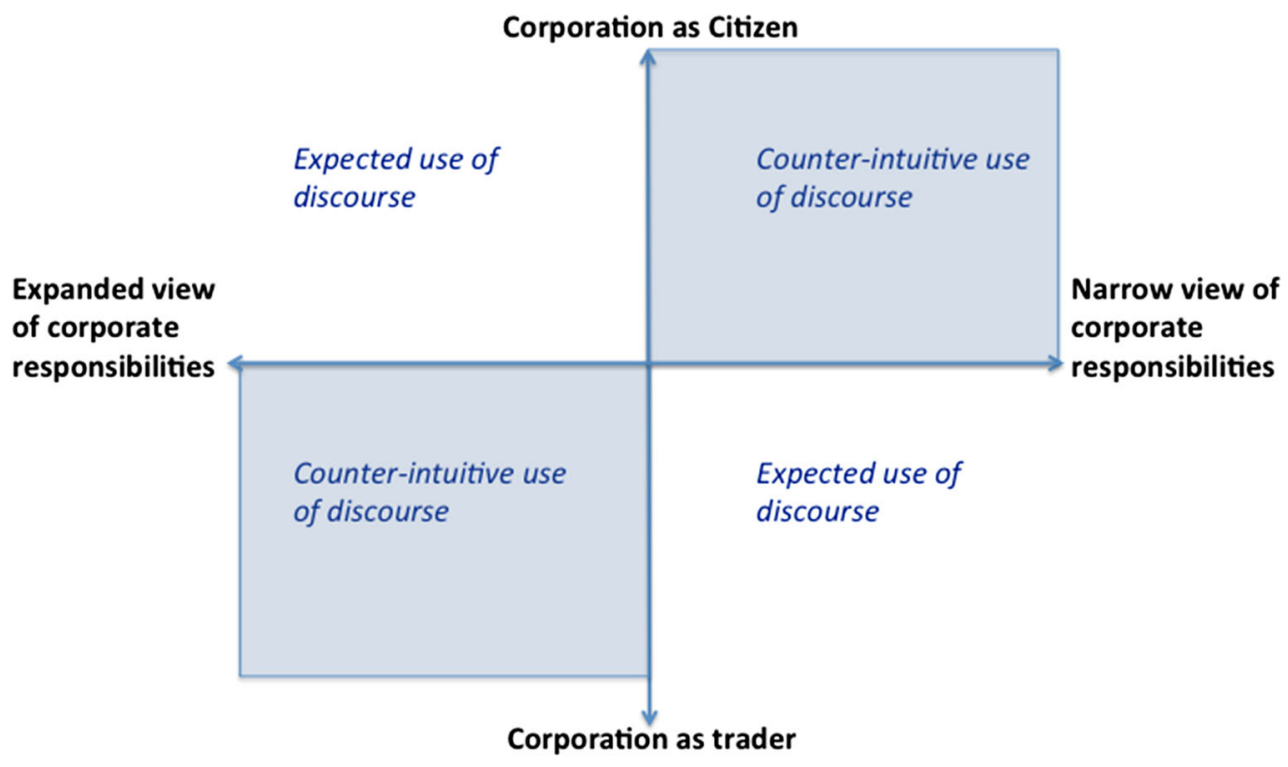


of the legislation and thereby placed these different strategies in context. Such analyses would also be well placed to draw inferences regarding the way in which power differentials affect legislative and institutional outcomes, something that the present study was equally not designed to ascertain.

\section{Conclusion}

Many of our twenty first century corporations are tied to contexts such as the DRC, just as the predecessor of the modern corporation, the East India Company, which Robins (2002) dubs the first transnational corporation:

...the underlying thirst for bullion in the East forced a powerful linkage with the growing slave economies of the Atlantic. A terrible triangle was formed with African slaves being purchased in part with Indian cotton goods, then being sold in the Americas for new-mined gold and silver, which in turn found its way via London to India where it procured more textiles. And as tea succeeded Indian textiles as its most profitable product, so the Company sought ways to equally dominate the trade with China (Robins 2002, pp. 80-81).

Looking back through the centuries at the East India Company, we realize their practices trading in Gold, Textiles, Tea and Slaves were abhorrent. There is no contemporary analogue for this gruesome supply chain. Yet, notwithstanding more complex manufacturing processes and global supply and consumption chains, corporations and their regulators are helping to perpetuate modern slavery and human exploitation (Crane 2013). Is it more plausible for the corporation to cast itself as a nexus of contracts, passive in the face of a Gordian knot of transactions? Or is it inevitably, and unwillingly perhaps, a citizen on the world stage that acknowledges its connectedness within global production networks? Rather than more narrow contract responsibility the latter calls for full responsibility for the human rights impacts that are linked to operations upstreaming the value chain (SchrempfStirling et al. 2012; Reinecke and Ansari 2015). Here we join a conversation in the Journal of Business Ethics on the responsibilities of the corporate citizen in developing contexts (Agbiboa 2012; Janssen et al. 2013; Rotter et al. 2013), CSR "rhetoric" (Driver 2006; Kallio 2007; Sethi 2014) and public good (Carcello 2009; Morrell and Clark 2010; O'Brien 2009). Our specific contribution to this debate is to highlight the wavering nature of rhetoric on both sides of the divide. Corporations and their adversaries each employ 'citizen' and 'trader' arguments. However, analysis reveals that the politico-ideological coordinates underlying this rhetoric are readily identifiable. CSR discourse, even when appearing to change direction depending on prevailing institutional winds, can be revelatory of more fixed material interests. It is the responsibility of researchers to penetrate discursive façades and expose the political programmes that underpin CSR rhetoric.

While the context of conflict minerals throws up important questions for understanding corporate responsibility, it also prompts questions for us as consumers. If the phone in our pocket relies on components sourced in wartorn $\mathrm{DRC}$, then to what extent are we (ethically) responsible? The globalized nature of supply chains, manufacturing industries and the consumer goods industry seem to confront consumers with an impossibly high, Kantian standard for responsibility. On the one hand, schemes have emerged that enable consumers to source tea, flowers or fruit responsibly. For instance, by earmarking products as "fair", Fair Trade helps ethical consumers (understood broadly) offset problems in how, global capitalism distances them from producers (Morrell and Jayawardhena 2010; Reinecke 2010). On the other hand, this means that an ethical consumer relies on third-party arbiters of fairness: the Fairtrade standard setter or the SEC. This requires a shared and generalizable view of corporate responsibility-of what it is fair for firms to do.

But the SEC is less like an independent arbiter than it is a flawed and partial clearing house for complexity and rhetorical clutter: a space where dust is thrown up by both sides of the rival corporation-as-trader and corporation-as-citizen camps. Our analysis shows how neither of these camps sticks to a principled view, in the sense that each will wear the other's clothing if it is the more effective way to press their cause. As a discipline perhaps we too are failing because in providing rival accounts of CSR, rather than ideologically fixed signposts that might anchor debate, we have furnished both with constructions that are weathervanes. The implication of this goes broader than questioning whether CSR is rhetoric, instead we need to accept the role CSR plays as rhetoric, in shaping how responsibility itself is constructed.

Finally, a note of caution on the prominent role that the 'conflict minerals' problem has played in shaping public and political discourse. The Dodd Frank Act has, among other things, drawn attention to the situation in the DRC. However, there is a danger if conventional wisdom comes to attribute the DRC's problems primarily to local mismanagement of resources leading to a 'resource curse'. Longue durée histories of the DRC tend to view conflict minerals as a more recent manifestation of how "the wealth of the country has leaked away abroad" (Trapido 2015). According to Trapido (2015), conflict minerals are a correlate to the dual curses of capital flight and being stuck in a primitive phase of capital accumulation-money made in 
the DRC tends to end up in tax havens off-shore instead of being reinvested in infrastructure and development. The militarized scramble for resources exploded after the overthrow of Mobutu in the 1990s (Trapido 2015), but the often violent integration of DRC's minerals into international capital circuits started with the colonial exploitation of the country. Therefore, as important as it is to analyse discursive shenanigans surrounding the 'conflict minerals' problem, placing conflict minerals at the root of the conflict should be recognized as a causal construction that aims at 'taming' the wicked problem (Reinecke and Ansari 2015), but it is only the tip of the iceberg as far as the DRC's governance problems are concerned.

Open Access This article is distributed under the terms of the Creative Commons Attribution 4.0 International License (http://creative commons.org/licenses/by/4.0/), which permits unrestricted use, distribution, and reproduction in any medium, provided you give appropriate credit to the original author(s) and the source, provide a link to the Creative Commons license, and indicate if changes were made.

\section{References}

\section{Primary Sources}

Comment letters on proposed disclosure legislation available from: http://www.sec.gov/comments/s7-40-10/s74010.shtml

OECD. (2013). OECD due diligence guidance for responsible supply chains of minerals from conflict-affected and high-risk areas (2nd ed.). Paris: OECD Publishing. doi:10.1787/9789264185050-en.

SEC. (2011). Roundtable on conflict minerals, October 18, 2011. Available from: https://www.sec.gov/news/otherwebcasts/2011/ conflictmineralsroundtable 101811.shtml

SEC. (2012). 17 CFR PARTS 240 and 249b, Release No. 34-67716; File No. S7-40-10 [final rules) available from: http://www.sec. gov/rules/final/finalarchive/finalarchive2012.shtml

\section{Secondary Sources}

Agbiboa, D. E. (2012). Between corruption and development: The political economy of state robbery in Nigeria. Journal of Business Ethics, 108(3), 325-345.

Archel, P., Husillos, J., \& Spence, C. (2011). Loading the dice of corporate social responsibility discourse: The institutionalisation of managerial capture. Accounting, Organizations and Society, 36, 327-343.

Bachrach, P., \& Baratz, M. S. (1970). Power and poverty: Theory and practice. Oxford: Oxford University Press.

Bealing Jr, W. E. (1994). Actions speak louder than words: An institutional perspective on the securities and exchange commission. Accounting, Organizations and Society, 19(7), 555-567.

Bozanic, Z., Dirsmith, M. W., \& Huddart, S. (2012). The social construction of regulation: The endogenization of insider trading laws. Accounting, Organizations and Society, 37, 461-481.

Carcello, J. V. (2009). Governance and the common good. Journal of Business Ethics, 89(1), 11-18.

Coase, R. H. (1937). The nature of the firm. Economica, 4(16), 386-405.
Crane, A. (2013). Modern slavery as a management practice: Exploring the conditions and capabilities for human exploitation. Academy of Management Review, 38(1), 49-69.

Driver, M. (2006). Beyond the stalemate of economics versus ethics: Corporate social responsibility and the discourse of the organizational self. Journal of Business Ethics, 66(4), 337-356.

Friedman, M. 1970. The social responsibility of business is to increase its profits, New York Times.

International Rescue Committee (IRC). (2007). Mortality in the democratic republic of congo-an ongoing crisis. Available from: http://www.rescue.org/sites/default/files/resource-file/2006-7_con goMortalitySurvey.pdf

Janssen, C., Vanhamme, J., Lindgreen, A., \& Lefebvre, C. (2013). The Catch-22 of responsible luxury: Effects of luxury product characteristics on consumers. Perception of fit with corporate social responsibility. Journal of Business Ethics, 119(1), 45-57.

Jensen, M., \& Meckling, W. (1976). Theory of the firm: Managerial behavior, agency costs and ownership structure. Journal of Financial Economics, 3, 305-360.

Jensen, M. C. (2002). Value maximization, stakeholder theory, and the corporate objective function. Business Ethics Quarterly, 12(2), 235-256.

Jones, T. M. (1980). Corporate social responsibility revisited, redefined. California Management Review, 22, 59-67.

Kallio, T. J. (2007). Taboos in corporate social responsibility discourse. Journal of Business Ethics, 74(2), 165-175.

Laclau, E. (2005). On populist reason. London: Verso.

Levy, D. L. (2005). Business and the evolution of the climate regime: The dynamics of corporate strategies. In D. Levy \& P. J. Newell (Eds.), The business of global environmental governance (pp. 74-104). Massachusetts: MIT Press.

Levy, D., Reinecke, J., \& Manning, S. (2015). The political dynamics of sustainable coffee: Contested value regimes and the transformation of sustainability. Journal of Management Studies,. doi:10.1111/joms.12144.

Margolis, J. D., \& Walsh, J. P. (2003). Misery loves companies: Rethinking social initiatives by business. Administrative Science Quarterly, 48(2), 268-305.

Matten, D., \& Crane, A. (2005). Corporate citizenship: Toward an extended theoretical conceptualization. Academy of Management Review, 30(1), 166-179.

Matten, D., Crane, A., \& Chapple, W. (2003). Behind the mask: Revealing the true face of corporate citizenship. Journal of Business Ethics, 45(1-2), 109-120.

Mellahi, K., Morrell, K., \& Wood, G. (2010). The ethical business (2nd ed.). Palgrave: London.

Milne, M. J., Kearins, K., \& Walton, S. (2006). Creating adventures in wonderland: The journey metaphor and environmental sustainability. Organization, 13(6), 801-839.

Morrell, K., \& Clark, I. (2010). Private equity and the public good. Journal of Business Ethics, 96(2), 249-263.

Morrell, K., \& Jayawardhena, C. (2010). Fair Trade. Ethical decision making and the narrative of gender difference, business ethics: A European review, 19(4), 393-407.

McWilliams, A., \& Siegel, D. (2001). Corporate social responsibility: A theory of the firm perspective. Academy of Management Review, 26(1), 117-127.

O'Brien, T. W. (2009). Reconsidering the common good in a business context. Journal of Business Ethics, 85(1), 25-37.

Reinecke, J. (2010). Beyond a subjective theory of value and towards a "Fair Price": An organizational perspective on fairtrade minimum price setting. Organization, 17, 563-581.

Reinecke, J., \& Ansari, S. (2015). Taming wicked problems: The role of framing in the construction of corporate social responsibility. Journal of Management Studies, doi:10.1111/joms.12137. 
Robins, N. (2002). Loot: In search of the East India Company, the world's first transnational corporation. Environment and Urbanization, 14(1), 79-88.

Rotter, J. P., Airike, P. E., \& Mark-Herbert, C. (2013). Exploring political corporate social responsibility in global supply chains. Journal of Business Ethics, 125, 581-599.

Scherer, A. G., \& Palazzo, G. (2007). Toward a political conception of corporate responsibility: business and society seen from a Habermasian perspective. Academy of Management Review, 32(4), 1096-1120.

Scherer, A. G., \& Palazzo, G. (2011). The new political role of business in a globalized world: A review of a new perspective on CSR and its implications for the firm, governance, and democracy. Journal of Management Studies, 48(4), 899-931.

Schrempf-Stirling, J., Palazzo, G., \& Phillips, R. A. (2012). Ever expanding responsibilities: Upstream and downstream corporate social responsibility. In A. Lindgreen, F. Maon, J. Vanhamme, \& S. Sen (Eds.), Sustainable value chain management: Analyzing, designing, implementing, and monitoring for social and environmental responsibility (pp. 353-368). Farnham: Ashgate.

SEC. (2014). The investor's advocate. Available from: http://www. sec.gov/about/whatwedo.shtml\#.VFnm8UhWU4Q, 16 April 2015.
Sethi, S. P. (2014). John Gerard Ruggie, just business: multinational corporations and human rights. Journal of Business Ethics, 123(2), 361-362.

Shatz, A. (2014). Ca va un peu. London Review of Books, 36(20), $31-33$.

Spence, C. (2007). Social and environmental reporting and hegemonic discourse. Accounting, Auditing and Accountability Journal, 20(6), 855-882.

Spence, C. (2009). Social accounting's emancipatory potential: A Gramscian critique. Critical Perspectives on Accounting, 20(2), 205-227.

Trapido, J. (2015). Africa's leaky giant. New Left Review, 92, 5-42.

Tregidga, H., Milne, M., \& Kearins, K. (2014). (Re)presenting 'sustainable organizations'. Accounting, Organizations and Society, 39, 477-494.

Unites States Code, Sarbanes-Oxley Act of 2002, PL 107-204, 116 Stat 745, Codified in Sections 11, 15, 18, 28, and 29 USC, July 2002

Waddell, S. (2000). New institutions for the practice of corporate citizenship: Historical, intersectoral and develpmental perspectives. Business and Society Review, 105(1), 107-126.

Young, J. J. (2014). Separating the political and the technical: Accounting standard-setting and purification. Contemporary Accounting Research, 31(3), 713-747. 